\title{
研究ノート
}

\section{Hydrolysis of Sodium Phytate in Growing Mice}

\author{
Tsutomu Yoshida and Shoko Shinoda \\ Department of Food and Nutrition, Tachikawa College of Tokyo
成長中マウスにおけるフィチン酸ナトリウムの分解
吉田勉, 篠田粧子 東京都立立川短期大学食物学科

\begin{abstract}
試料中フィチン酸含量を測定するためには，まずフィチン酸を溶液中に抽出する必要があるため, 飼料およ び翼中のフィチン酸の抽出に要する回数を検討した。その結果, $1.2 \% \mathrm{HCl}$ 溶液に上る抽出回数は, 飼料で は 3 回, 顀では 5 回で十分なことがかかった。また, 上記抽出液中でのフィチン酸の分解を防ぐには, 冷蔵庫 内 $\left(5^{\circ} \mathrm{C}\right)$ で 1 カ月以内の保存が望ましいと思われた。

マウス排䔬後 2 時間以内に集めた䔬です，それ以降24時間まで室温放置した後に集めた蕒でも，䔬中フィチ ン酸含量には差がなかったので, 室温に 1 日以内放置した蕒中のフィチン酸の合成分解は問題にする必要がな いと考えられた。フィチン酸ナトリウムを $0.64 \%$ (乾物中) 含有する精製飼料を給与された成長中マウスは, フィチン酸中リン酸の約 $65 \%$ 加水分解した。
\end{abstract}

Jap. J. Nutr., 40 ( 5 ) 269 273 (1982)

It is generally recognized that phytate $P$ is available to ruminants and monogastric animals under appropriate conditions ${ }^{1)}$ and that the presence of undegraded phytate in the intestines decreases the absorption of essential dietary minerals ${ }^{23)}$. However, no work has been conducted on the amount of phytate $\mathrm{P}$ hydrolyzed by mice. Phytate extraction from the feces is required for fecal phytate determination. Nevertheless, few experiments show data on the extraction of fecal phytate. This study is concerned with experiments of the required number of phytate extractions from feces by $\mathrm{HCl}$ solution and of the ability of growing mice to hydrolyze phytate $\mathrm{P}$ in diet containing sodium phytate.

\section{Experiment}

Inbred $\mathrm{C} 3 \mathrm{H}$ male mice of the National Institute of Radiological Sciences strain were used. Throughout the experimental periods, the mice were housed in plastic cages (three animals each) with wire screen bottoms, kept in the animal room at $23 \pm 3^{\circ} \mathrm{C}$, and given their respective diets and deionized water ad libitum. After a 5-day adjustment period, feed intake and body weight were measured for 1 week at the age of 5 weeks. The feces for phytate analysis were collected daily within 2 hours after defecation. The mice were given pelleted purified diets ${ }^{3 / 4)}$ containing $1 \% \mathrm{Cr}_{2} \mathrm{O}_{3}$ without sodium phytate $(\mathrm{L}-488 \mathrm{FCr}$ ) or with sodium phytate (L-488FCrP1, sodium 
phytate from the Sigma Chemical Co., USA), which were sterilized by autoclaving for 30 minutes at $121^{\circ} \mathrm{C}$.

The Allen method ${ }^{5}$ was used for determination of P. For the determinaton of phytate $\mathrm{P}, \mathrm{a}$ modified method $^{6)}$ of Oberleas ${ }^{7}$ was used with two additional modifications: for the extraction of phytate $\mathrm{P}$ from the samples, $1.2 \% \mathrm{HCl}$ solution was used instead of $1.2 \% \mathrm{HCl}$ containing $\mathrm{Na}_{2} \mathrm{SO}_{4}$

( $1 \mathrm{~g}$ of defatted sample to be extracted was added to a flask containing $25 \mathrm{~m} l$ of $1.2 \% \mathrm{HCl}$, shaken for 1.5 hours, and then filtered.); the extracts of the samples were treated with $\mathrm{FeCl}_{3}$ solution plus a few drops of $\mathrm{Na}_{2} \mathrm{SO}_{4}{ }^{8)}$ to precipitate ferric phytate instead of $\mathrm{FeCl}_{3}$ solution. Phytate $\mathrm{P}$ content of $\mathrm{L}-488 \mathrm{FCrP} 1$ was $0.129 \%(0.640 \%$ as sodium phytate $)$ on dry basis.

\section{Results and Discussion}

When $1.2 \% \mathrm{HCl}$ solution was used for the extraction of phytate from the diets, no dietary $\mathrm{P}$ was found in the fourth solution for extraction as shown in table 1. It was also observed from table 1 that $P$ and phytate $P$ after fourth extraction from feces were negligible. Therefore, three and five extractions in $1.2 \% \mathrm{HCl}$ are satisfactory for phytate determination of diet and feces, respectively. Unextracted $\mathrm{P}$ (total $\mathrm{P}$-extracted total $\mathrm{P}$ ) was 1.4 to $1.5 \mathrm{mg} / \mathrm{g}$ of dry matter of the diets. It is supposed that the unextracted $\mathrm{P}$ mainly originated from casein in the diets ${ }^{9}$.

Phytate in $1.2 \% \mathrm{HCl}$ was kept in a refrigerator $\left(5^{\circ} \mathrm{C}\right)$ until the analysis. Therefore, destruc. tion of phytate may have occurred during storage. In order to explore this possibility, the

Table $1 \mathrm{P}$ extraction from autoclaved diet and feces of mice by $1.2 \% \mathrm{HCl}$

(mg/g of dry matter)

\begin{tabular}{|c|c|c|c|c|c|c|c|}
\hline & \multirow{2}{*}{ Total } & \multicolumn{6}{|c|}{ Extracted } \\
\hline & & $1 \mathrm{st}$ & 2nd & $3 \mathrm{rd}$ & 4 th & 5 th & Total \\
\hline \multicolumn{8}{|l|}{ Autoclaved diet } \\
\hline $\mathrm{P}$ of $\mathrm{L}-488 \mathrm{FCr} *$ & 6.71 & 4. 78 & 0.52 & 0 & 0 & - & 5.30 \\
\hline $\mathrm{P}$ of $\mathrm{L}-488 \mathrm{FCrP} 1 * *$ & 8.14 & 5.77 & 0.80 & 0.05 & 0 & - & 6.62 \\
\hline \multicolumn{8}{|c|}{ Feces of mice fed Diet L-488FCrP1** } \\
\hline $\mathrm{P}$ & 27.13 & 15.71 & 3. 46 & 0.93 & 0.35 & 0.13 & 20.58 \\
\hline Phytate P & - & 2.57 & 0.66 & 0.29 & 0.16 & 0.06 & 3. 74 \\
\hline
\end{tabular}

* : Sodium phytate-free diet.

** : Sodium phytate containing diet.

Table 2 Change of phytate $\mathrm{P}$ content in $1.2 \% \mathrm{HCl}$ during storage in a refrigerator

\begin{tabular}{ccccr} 
& & & $(\mathrm{M} \pm \mathrm{SD}, n=4)$ \\
\hline 0 day & 1 week & 2 weeks & 1 month & 2 months \\
$1.66 \pm 0.09$ & $1.71 \pm 0.08$ & $\mathrm{P} \mathrm{mg} / 200 \mathrm{~m} l^{*}$ & & \\
\hline
\end{tabular}

* $: 1 \%$ of sodium phytate was added to the solution extracted with $1.2 \% \mathrm{HCl}$ from Diet L-488FCr (Sodium phytate-free diet). 
Table 3 Fecal phytate $\mathrm{P}$ content and the rate of hydrolysis of phytate $\mathrm{P}$ in young mice fed Diet L-488FCrP1 (Sodium phytate containing diet) $\quad(\mathrm{M} \pm \mathrm{SD}, n=4)$

\begin{tabular}{|c|c|c|c|c|}
\hline Feces $1^{*}$ & Feces $2^{* *}$ & Intake (A) & excretion (B) & \multirow{2}{*}{ Rate of hydrolysis $\left(\frac{\mathrm{A}-\mathrm{B}}{\mathrm{A}} \%\right)$} \\
\hline \multicolumn{2}{|c|}{$\mathrm{mg} / \mathrm{g}$ of dry matter } & \multicolumn{2}{|c|}{$\mathrm{mg} /$ day/mouse } & \\
\hline $0.371 \pm 0.037$ & $0.378 \pm 0.054$ & $25.4 \pm 1.6$ & $8.72 \pm 0.95$ & $65.5 \pm 5.1$ \\
\hline
\end{tabular}

$*$ : Feces collected within 2 hours after defecation.

**: Feces collected within 24 hours after defecation excluding Feces 1.

following experiment was conducted. About $1 \%$ of sodium phytate was added to the solution extracted with $1.2 \% \mathrm{HCl}$ from phytate-free diet $(\mathrm{L}-488 \mathrm{FCr})$ and stored in a refrigerator for 2 months. Table 2 shows that there were no significant differences in phytate $\mathrm{P}$ content among the solutions at each period of storage. This suggests that at least 1 month storage is appliable.

Mellanby ${ }^{10)}$ was unable to detect any phytate in the urine and other tissues of dogs. In our experiment, only traces of phytate $P$ were recovered in the feces and urine of mice when they were fed the phytate-free diet $(\mathrm{L}-488 \mathrm{FCr})$. Therefore, the possibility of synthesis of phytate in the intestine can be denied.

The phytate $\mathrm{P}$ content of the feces from mice fed Diet L-488FCrP1 and the rate of hydrolysis of phytate $\mathrm{P}$ are shown in table 3. It was reported that phytate added to the feces of ruminants was partly broken down in 1 week at $0^{\circ} \mathrm{C}^{11}$. But, Jenkins ${ }^{12)}$ observed an increase in the phytate content of moist hen droppings kept at $10 \sim 16^{\circ} \mathrm{C}$ over a period of 1 week. A comparison of the phytate $\mathrm{P}$ contents between Feces 1 (collected within 2 hours after defecation) and Feces 2 (collected within 24 hours after defecation excluding Feces 1 ) showed that the breakdown or synthesis of fecal phytate is unlikely to occur to an appreciable degree when feces of mice are kept at room temperature for 1 day.

The ability of various species of animals to hydrolyze phytate in the intestine varies. Because of microbial phytase in the rumen, cattle ${ }^{13}$ ) and sheep ${ }^{14}$ hydrolyze most natural phytate, whereas chicks and laying hens hydrolyze only small amounts of natural phytate ${ }^{14}$ ). Rats are able to utilize both natural ${ }^{15) \sim 20)}$ and synthetic forms of phytate ${ }^{21) \sim 25)}$. Canals et al. ${ }^{28)}$ fed ${ }^{22} \mathrm{P}-$ labeled phytin to experimental animals including mice and found that the ${ }^{32} \mathrm{P}$ was deposited in various tissues. The results obtained in table 3 show that growing mice also had the ability to hydrolyze phytate.

Ranhotra $e t a l{ }^{25)}$ observed that the amount of phytate hydrolyzed was about $75 \%$ in 9 weeks old rats fed the diet supplemented with $0.62 \%$ sodium phytate. Several workers have reported that young rats fed diets containing moderate amounts of calcium hydrolyzed natural phytate by $44 \%^{20)}, 57 \sim 66 \%{ }^{18)}$ or $71 \sim 74 \%{ }^{17)}$. Our experiment showed that, about $65 \%$ of sodium phytate was hydrolyzed in growing mice. This indicates that there is no appreciable difference between mice and rats in ability to hydrolyze phytate. 
A previous paper ${ }^{3}$ ) showed that apparent digestibility of total $\mathrm{P}$ (phytate $\mathrm{P}+$ non-phytate $\mathrm{P}$ ) was about $65 \%$ in mice fed Diet $\mathrm{L}-488 \mathrm{FCrP} 1$ and the value was very similar to that measured by phytate $\mathrm{P}$ in the present experiment. Therefore, it is probable that phytate $\mathrm{P}$ and nonphytate $\mathrm{P}$ are almost equally digested in mice under those experimental conditions.

This study indicated that growing mice are able to hydrolyze sodium phytate to a considerable degree. Whether this was brought about by intestinal or by bacterial phytase remains to be elucidated.

\section{Summary}

In phytate extraction for the determination of dietary and fecal phytate, three and five extrac. tion steps by $1.2 \% \mathrm{HCl}$ were satisfactory.

A storage period of within 1 month in a refrigerator $\left(5^{\circ} \mathrm{C}\right)$ was considered desirable to prevent destruction of phytate in the sample solutions extracted by $1.2 \% \mathrm{HCl}$.

Appreciable breakdown or synthesis of phytate was unlikely to occur when the feces of mice were kept at room temperature for 1 day.

Growing mice had the ability to hydrolyze phytate (about 65\%) when they were fed purified diets containing $0.64 \%$ sodium phytate.

The authors thank Dr. Matsumoto, T., Chief Researcher of the National Institute of Radiological Sciences, for the supply of mice; Dr. Watarai, S., Director of the Institute of Laboratory Animals of the Funabashi Nohjo Co., for the preparation of the diets; and Misses Adachi, S., Ogawa, C., Odaka, M., Obata, A., Kato, M. and Yoshikawa, K. for their technical assistance.

\section{References}

1) Taylor, T. G.: Proc. Nutr. Soc., 24, 105 (1965)

2) Cosgrove, D. J. and Irving, C. C. J. : Inositol Phosphates, p.157 (1980) Elsevier Scientific Pub. Co., New York

3) Yoshida, T., Shinoda, S., Matsumoto, T. and Watarai, S. : J. Nutr. Sci. Vitaminol., 28, 401 (1982)

4) Wostmann, B. S., Bruckner-Kardoss, E., Beaver, M., Chang, L. and Madsen, D. : J. Nutr., 106, 1782 (1976)

5) Allen, R. J. L. : Biochem. J., 34, 858 (1940)

6) Yoshida, T., Shinoda, S. and Watarai, S. : Jap. J. Nutr., 38, 215 (1980)

7) Oberleas, D. : The determination of phytate and inositol phosphates, In Glick, D. ed. “Methods of Biochemical Analysis”, Vol. 20, p. 97 98 (1971) Wiley, New York

8) Saio, K. and Hondo, M. : Proc. of 25th Meeting of Japan, Food Technology, p. 21 (1978)

9) Kon, S. K. and Cowie, A. T. : Milk, the Mammary Gland and Its Secretion, Vol. 2, p. 207 (1961) Acad. Press, New York

10) Mellanby, E. : A Story of Nutritional Research (1950) Williams and Wilkins Co., Baltimore. Cited in 2) 
11) Reid, J. L., Franklin, M. C. and Hallsworth, E. G. : Australian Vet. J., 23, 136 (1947)

12) Jenkins, N. K. : Nature, 205 (4966), 89 (1965)

13) Nelson, T. S., Daniels, L. B., Hall, J. R. and Shields, L. G. : J. Anim. Sci., 42, 1509 (1976)

14) Nelson, T. S. : Poultry Sci., 55, 194 (1976)

15) Spitzer, R. R. and Phillips, P. H. : J. Nutr., 30, 183 (1945)

16) Bouthwell, R. K., Geyer, R. P., Halverson, A. W. and Hart, E. B. : J. Nutr., 31, 193 (1946)

17) Nelson, T. S. and Kirby, L. K. : Nutr. Rep. Int., 20, 729 (1979)

18) Taylor, T. G. and Coleman, J. W. : Brit. J. Nutr., 42, 113 (1979)

19) Nahapatian, A. and Young, V. R.: J. Nutr., 110, 1458 (1980)

20) Moore, R. J. and Veum, T. L. : Nutr. Rep. Int., 25, 221 (1982)

21) Krieger, C. H. and Steenbock, H. : J. Nutr., 20, 125 (1940)

22) Krieger, C. H., Bunkfeldt, R., Thompson, C. R. and Steenbock, H. : J. Nutr., 21, 213 (1941)

23) Spitzer, R. R., Maruyama, G., Michaud, L. and Phillips, P. H. : J. Nutr., 35, 185 (1948)

24) Likuski, H. J. A. and Forbes, R. M. : J. Nutr., 85, 230 (1965)

25) Ranhotra, G. S., Loewe, R. J. and Puyat, L. V.: Cereal Chem., 51, 323 (1974)

26) Canals, E., Marignan, R. and Cordier, S. : Bull. Soc. Chim. Biol., 36, 1015 (1954)

（受付 : 昭和57年 7 月 21 日） 